\title{
ARTIGO
}

\section{E se a barragem romper?}

\section{O extrativismo e os "efeitos derrame de risco" no Município de Raposos - MG ${ }^{1}$}

\author{
Junia Ferrari ${ }^{2}$ | Clarice Flores Fialho ${ }^{3}$ | Maria Isabel Tamião Santana ${ }^{4}$ | Maria Moura
} Soalheiro ${ }^{5}$

Como citar este artigo: FERRARI, Junia et al. O extrativismo e os "efeitos derrame de risco" no Município de Raposos - MG. Revista de Ciências do Estado. Belo Horizonte: v. 5, n. 1, e16073. ISSN: 2525-8036.

Resumo: O discurso do desenvolvimento tem se apoiado no extrativismo como alternativa para os países que detêm grandes reservas de recursos naturais. O estado de Minas Gerais, motivado por este entendimento, tem sustentado uma relação de dependência histórica com a mineração, na qual predomina a contabilização dos lucros em detrimento dos diversos efeitos decorrentes desta prática. Para o sociólogo Gudynas, esse modelo de extrativismo tem repercussões que vão além do local de exploração, atingindo o meio ambiente, o território, a economia, dentre outros, às quais ele denomina por "efectos derrame". A partir dessa categorização e do estudo de caso do município de Raposos (MG), este trabalho propõe uma nova modalidade de análise que inclui os efeitos decorrentes da ameaça cotidiana de ruptura de três barragens de rejeitos na região, e que aqui nomeamos por "efeitos derrame de risco".

Palavras-chave: desenvolvimento; extrativismo; mineração; risco; efeito derrame.

Recebido em 18.11.2019

Aprovado em 17.12.2019

Publicado em 17.03.2020

\footnotetext{
${ }^{1} \mathrm{O}$ núcleo central deste artigo foi apresentado, oralmente, em uma sessão do XVIII Seminário de Economia Mineira - A crise da Mineração e as perspectivas Econômicas, Sociais e Ambientais de Minas Gerais e Brasil -, em Agosto de 2019, na cidade de Diamantina, MG. Agradecemos os comentários e sugestões dos pareceristas anônimos da Revista Ciências do Estado pelas imprescindíveis e valiosas contribuições à versão final deste artigo, e também o apoio da Pro-reitoria de Pesquisa (PrPq) e da Pró-reitoria de Extensão (PROEX) da Universidade Federal de Minas Gerais (UFMG), na forma de bolsas concedidas aos graduandos que participaram deste trabalho.

${ }^{2}$ Doutora em Arquitetura e Urbanismo pela Universidade Federal de Minas Gerais, Professora do Departamento de Urbanismo da Escola de Arquitetura da UFMG e Coordenadora do Lab-Urb - Laboratório de Estudos Urbanos e Metropolitanos, na mesma instituição. e-mail: juniaferrari15@gmail.com

${ }^{3}$ Graduanda em Arquitetura e Urbanismo pela Universidade Federal de Minas Gerais e Bolsista de extensão pela PROEX-UFMG, sob orientação da Profa. Dra. Junia Ferrari. e-mail: clariceffialho@ gmail.com

${ }^{4}$ Graduanda em Arquitetura e Urbanismo pela Universidade Federal de Minas Gerais e Bolsista de extensão pela PROEX-UFMG, sob orientação da Profa. Dra. Junia Ferrari. e-mail: maria.isabel16santana@gmail.com

${ }^{5}$ Graduanda em Arquitetura e Urbanismo pela Universidade Federal de Minas Gerais e Bolsista de extensão pela PROEX-UFMG, sob orientação da Profa. Dra. Junia Ferrari. e-mail: maria.moura.mms@gmail.com
} 


\section{INTRODUÇÃO}

A mineração, no Estado de Minas Gerais, é uma atividade que remonta ao século XVII, quando o ouro é descoberto na região, e se mistura com a história de fundação de várias das suas cidades. Desde então, as riquezas minerais têm marcado sua memória de diversas formas: na opulência da arquitetura de suas igrejas barrocas e nas toneladas de minério que pesam favoravelmente na balança comercial do Estado $^{6}$, mas também em importantes lutas como a Inconfidência Mineira ${ }^{7}$ e no recente movimento "Mar de Lama nunca mais" ${ }^{8}$. Além dos registros profundos na história e nas cidades mineiras, o extrativismo mineral também deixou marcas na vida cotidiana e, consequentemente, na cultura, sendo tema recorrente da literatura de Drummond, que por diversas vezes se manifestou contrário e preocupado "com a mineração cega às suas consequências" e com "os danos de várias ordens que via ou prévia no avanço da mineração" (WISNIK, 2018, p.19).

Ultimamente, o tema tem sido objeto de discussão em diversas esferas devido aos impactos gerados pelo rompimento das barragens de rejeitos em Mariana e Brumadinho, em 2015 e 2019, respectivamente. Infelizmente, essas não foram as primeiras e, ao que parece, podem não ser as últimas tragédias causadas pela mineração no Estado. Segundo o site do Comitê da Bacia Hidrográfica do Rio das Velhas, Minas Gerais possui em torno de 400 barragens ligadas ao setor minerário, sendo que mais de 300 destas estão localizadas no Quadrilátero Ferrífero ${ }^{9}$. Algumas, inclusive, se encontram na condição de alerta máximo em relação ao risco de ruptura marcando, de forma perversa, o cotidiano de várias comunidades.

Segundo a Agência Nacional de Mineração (ANM), desde o dia 27 de março de 2019, as barragens B3/B4 da Mina Mar Azul, em Macacos (distrito de Nova Lima), e as barragens Forquilhas 1 e 3, em Ouro Preto, tiveram seus respectivos níveis de segurança alterados de 2 para 3 , o que significa estarem sob risco iminente de ruptura, com impacto direto nos municípios de Ouro Preto, Nova Lima, Itabirito, Rio Acima, Raposos e Sabará, além de consequências, em níveis não divulgados, para os demais municípios que compõem a

\footnotetext{
${ }^{6}$ Segundo dados do Sumário Mineral (Ministério das Minas e Energias), a produção brasileira de minério de ferro, em 2015, foi de 411,8 milhões de toneladas, das quais $68,4 \%$ foram extraídas no Quadrilátero Ferrífero.

7 A Inconfidência Mineira foi um importante movimento do final do século XVIII (1789), resultado da insatisfação da população da capitania das Minas Gerais com a rigorosa política fiscal imposta pela Coroa portuguesa para cobrança dos tributos sobre a mineração de ouro e diamantes na região.

${ }^{8}$ O movimento "Mar de Lama Nunca Mais" foi uma iniciativa da Associação Mineira do Ministério Público (AMMP), em parceria com o Centro de Apoio Operacional das Promotorias de Meio Ambiente, Patrimônio Histórico Cultural, Habitação e Urbanismo (CAOMA) a fim de elaborar um projeto de lei de iniciativa popular "para estabelecer normas de segurança para as barragens destinadas à disposição final ou temporária de rejeitos de mineração no Estado". A campanha contou com o apoio da sociedade civil, das organizações ambientais e dos órgãos de Meio Ambiente e foi aprovado na Assembleia Legislativa de Minas Gerais em fevereiro de 2019, por unanimidade entre os 65 deputados presentes. Trata-se do Projeto de Lei 3.676/16.

${ }^{9}$ Disponível em http://cbhvelhas.org.br/noticias/bomba-relogio/.
} 
bacia hidrográfica do Rio das Velhas ${ }^{10}$. Dentre esses municípios, destacamos aqui a cidade de Raposos que integra, juntamente com outros 33 municípios, a Região Metropolitana de Belo Horizonte (RMBH), e cuja origem remonta ao primeiro ciclo de mineração no Estado, ainda no século XVII. Como se trata de comunidade implantada ao longo do Rio das Velhas, a expectativa é que o rompimento de qualquer dessas barragens possa carrear lama de rejeitos que atingirão a cidade em até 10 metros acima do nível do rio ${ }^{11}$, o que significa destruição das áreas de várzea, além do isolamento em relação a boa parte da $\mathrm{RMBH}$, uma vez que atingiria a única ponte que liga a rodovia de acesso a Belo Horizonte ao centro de Raposos (ver Figura $01)$.

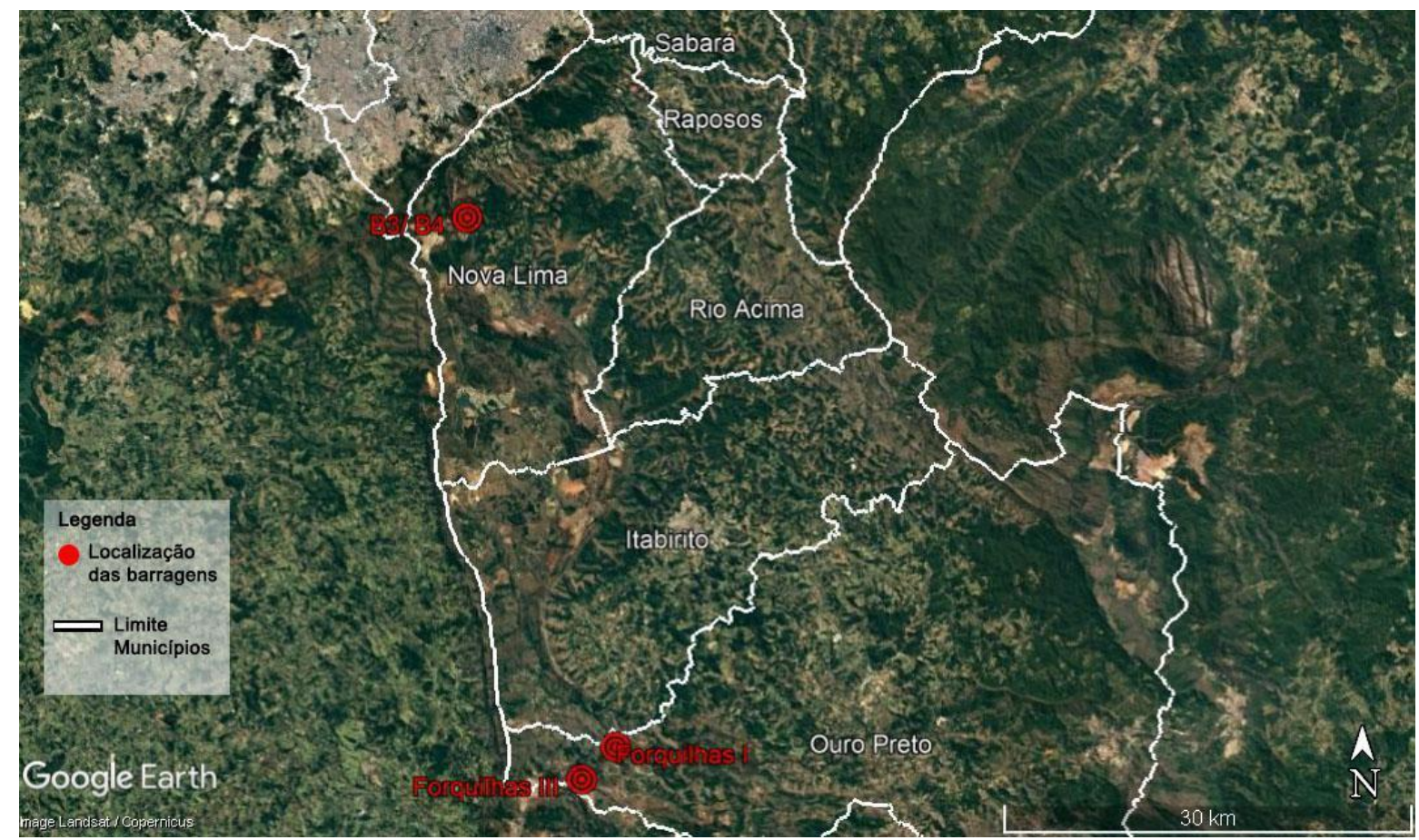

Figura 01: Vista Satélite dos municípios sob risco de rompimento e localização das barragens Forquilhas I e III (Ouro Preto) e B3/B4 (Macacos-Nova Lima) Fonte: CBH Rio das Velhas/ Reprodução própria , 2020.

Além do impacto direto que esses rejeitos podem provocar em Raposos - destruição de boa parte das edificações da cidade, mortes, comprometimento da ponte de acesso e

\footnotetext{
${ }^{10} \mathrm{O}$ rio das Velhas, importante curso d'água que compõe a bacia de mesmo nome e que é um dos principais contribuintes da bacia do Rio São Francisco, é responsável pelo abastecimento de água de boa parte da capital Belo Horizonte e de vários municípios da RMBH. No caso do rompimento de alguma dessas barragens, receberá a lama de rejeitos a partir de área conhecida como Alto Velhas, bem próxima de seu nascedouro (em Ouro Preto). Em síntese, pode ter suas águas contaminadas desde a origem, comprometendo a vida de diversas populações que habitam ao longo de seu percurso, e que dependem direta e indiretamente desse importante curso d’água.

${ }^{11}$ Segundo informação da equipe da Vale no dia da simulação do rompimento no município de Raposos.
} 
contaminação do Ribeirão da Prata $^{12}$-, outros efeitos sobre a vida dessas populações podem ser contabilizados na forma dos mais diversos tipos de riscos. São os chamados efectos derrames pelo sociólogo Gudynas (2015; 2018; 2019), entendidos como repercussões que vão além dos danos imediatos aos locais de exploração dos recursos, afetando as leis ambientais, a dependência econômica e a vida cotidiana nessas regiões.

Diante das consequências dos rompimentos em Mariana e Brumadinho ${ }^{13}$, bem como das informações (mesmo que ainda insuficientes e desencontradas) sobre os riscos iminentes das barragens implantadas na região ${ }^{14}$, vários segmentos da sociedade civil, do setor público e da comunidade acadêmica têm procurado tratar o tema do extrativismo mineral com mais atenção, somando outros aspectos a essas discussões. Diversos autores (ACOSTA, 2018; DILGER, LANG e PEREIRA FILHO, 2018; GUDYNAS, 2015) têm demonstrado que as repercussões dessas práticas se estendem para além dos riscos de ruptura das barragens. Sem deixar de reconhecer a relevância desses episódios e a gravidade dos danos locais, o que se pretende trazer para esta discussão são algumas das consequências do extrativismo que extrapolam as áreas de exploração alcançando espaços e tempos ampliados e, por isso, também merecem ser destacadas e incluídas no rol dos efeitos causadas pela atividade minerária.

O ambientalista e sociólogo uruguaio Eduardo Gudynas (2015; 2018; 2019) tem chamado a atenção para esses aspectos que ele denomina por "efectos derrame", ou seja, efeitos que extrapolam os danos locais provocados pelas atividades extrativas alcançando esferas da vida pouco exploradas pela literatura pertinente. Para o autor, o extrativismo geralmente é tratado apenas em relação à escala local, onde se dá a remoção dos recursos naturais. Entretanto, esta é apenas uma parte da grande cadeia que esta atividade abrange, uma vez que se encontra subordinada a critérios de preços e demandas estabelecidos por políticas econômicas em âmbito global. Segundo Gudynas (2015, p.14, grifos do autor), "sin embargo, los extractivismos despliegan efectos que van mucho más allá de la escala local, los cuales se 'derraman' sobre todo el país, en todo su territorio y en todos los sectores".

\footnotetext{
${ }^{12}$ O Ribeirão da Prata nasce na Serra do Gandarela e atravessa o município de Raposos. Como está próximo da sua nascente, exibe águas de excelente qualidade no município em poços muito utilizados pela população da RMBH. É contribuinte do Rio das Velhas, cujo encontro se dá ainda dentro de Raposos.

${ }_{13}$ Que contabilizam até agora em torno de 300 mortes e uma área ainda incalculável de destruição.

14 Apesar de sabermos o número de barragens oficialmente implantadas no Estado (pela Agência Nacional de Mineração), não há informações disponíveis sobre a condição de cada uma delas para consulta da população, bem como do número exato de barragens clandestinas e abandonadas. Em outros termos, não temos acesso facilitado às informações sobre os verdadeiros riscos que recaem, neste momento, sobre os territórios minerários de forma direta e indireta.
} 
Para se discutir e caracterizar esses efeitos é necessário, primeiramente, que se apresentem os sentidos atribuídos aos conceitos de desenvolvimento e de extrativismo, uma vez que as ambiguidades reveladas no uso desses termos podem nos conduzir a interpretações distintas e equivocadas, pelo menos no contexto deste trabalho. Assim, esta discussão se estrutura em uma primeira seção onde esses conceitos são apresentados em algumas de suas interpretações.

Em seguida, procurou-se apresentar as categorias dos chamados "efectos derrame" de Gudynas para, a partir delas, buscar as aproximações com fatos e episódios que têm permeado as histórias e o cotidiano daqueles que habitam o município de Raposos, em Minas Gerais. A escolha por essa comunidade se deu por algumas razões. Em primeiro lugar, por ser este um dos municípios diretamente afetados pelo risco iminente de ruptura das 03 barragens mencionadas anteriormente, o que nos leva a questionar qual o impacto dessas ameaças no cotidiano dessa comunidade. Em segundo lugar, porque este município, desde 2016, tem sido parceiro de um projeto de extensão do qual as pesquisadoras participam diretamente e que será tratado adiante de forma mais detalhada, o que permitiu uma boa aproximação com a comunidade. Além disso, Raposos guarda em sua história marcas profundas da mineração e, diferentemente da maioria das cidades que nasceu no ciclo do ouro, não exibe em seu conjunto urbano a opulência que os excedentes dessa atividade promoveu em outros locais. Pelo contrário, o município traz em sua bandeira a cor púrpura que simboliza as viúvas da mineração, além de diversos "efectos derrame" que repercutem em sua dinâmica social, econômica e ambiental. Segundo os argumentos que serão apresentados mais adiante, a cidade de Raposos também tem sido atingida em sua cotidianidade por mais um efeito da atividade mineradora que aqui nomeamos por "efeito derrame do risco". Em outros termos, a população passou a conviver, desde o primeiro semestre de 2019, com o risco iminente de ruptura de três barragens de rejeitos de mineração (que se encontram em alerta máximo), alterando seus hábitos e incluindo outros tipos de preocupações diárias - deslocamentos e escola dos filhos ameaçados; dificuldades para dormir; tensão constante; insegurança em relação à família, amigos e moradia -, sem que haja para isso um horizonte provável de finalização - o rompimento pode acontecer hoje, no próximo mês, daqui a um ano, ou mesmo não acontecer. Esta categoria de análise será tratada, de forma mais detalhada, na terceira seção deste trabalho. 


\section{DESENVOLVIMENTO E EXTRATIVISMO}

\subsection{DESENVOLVIMENTO COMO SINÔNIMO DE CRESCIMENTO?}

O termo desenvolvimento permite variadas interpretações e apropriações e, segundo o antropólogo Gustavo Lins Ribeiro (2008, pp.117), essa plasticidade é "central [justamente] para assegurar sua viabilidade continuada". Para o autor, essas variações - desenvolvimento industrial, capitalista, ambiental, sustentável etc. -, "refletem não apenas as experiências históricas acumuladas por diferentes grupos de poder em suas lutas por hegemonia internamente ao campo do desenvolvimento, mas também diferentes momentos de integração do sistema capitalista mundial" (idem, p.118). Para o antropólogo, entretanto, a matriz principal que orienta a conotação do termo está associada à ideia de progresso, ou seja, está ancorada na percepção, desde a Grécia Antiga, "de que os seres vivos experimentam o crescimento para amadurecer" (RIBEIRO, 1991, p. 68).

A noção de desenvolvimento associada a essa ideia de progresso e de um "processo linear e ininterrupto" (DILGER; PEREIRA FILHO, 2018, p.18) tem orientado a política econômica de vários países no sentido de se buscar o crescimento ilimitado como via única de promoção do bem-estar social, do progresso e do reconhecimento da nação no cenário econômico (e político) mundial. Nesse sentido, o termo desenvolvimento (e seus derivados, como desenvolvimentismo e neodesenvolvimentismo), largamente disseminado na mídia econômica e mesmo nas universidades como ideal de crescimento e progresso, permanece ancorado em um forte referencial que o consolida como sinônimo de algo positivo e, portanto, um fim a ser perseguido em nome do fortalecimento da soberania nacional (LANG, 2018).

$\mathrm{O}$ desenvolvimento também demanda uma parceria eficiente entre mercado e Estado - um pacto de governança -, além de estar fortemente vinculado a um sentimento de otimismo, pois está assentado no firme propósito de que é a receita para o crescimento. Em contrapartida, qualquer conduta ou prática que possa representar obstáculos à essa realização é considerada como retrocesso e estagnação, além de risco a ser removido. Segundo Ribeiro (2008), se opor à ideia de desenvolvimento é quase uma heresia.

De outra parte, o termo subdesenvolvimento passa a ser adotado para se referir aos países em condição oposta, ou seja, àquelas nações que não alcançaram o caminho do crescimento (e do desenvolvimento), permanecendo na condição de dependência econômica e exibindo números expressivos de população em estado de pobreza e miséria. O termo 
subdesenvolvimento tem sua origem, segundo Lang (2018), no discurso de posse de Harry Truman como presidente dos Estados Unidos, em $1949^{15}$.

Em sua fala, ele demonstra certa benevolência com os países de economia dependente (ou subdesenvolvidos, como ele cunhou). Entretanto, esse discurso civilizador dissimulava a real preocupação dos países centrais com o avanço do bloco socialista, especialmente após a Segunda Guerra. Assim, os EUA passam a mobilizar esforços no sentido de intensificar o controle sobre os países do sul global a partir de instituições mistas que assegurassem a formação de competências nas áreas de ciência, tecnologia e do management. Era uma forma indireta de se garantir a soberania do modo capitalista nas práticas econômicas, científicas e políticas desses países ditos subdesenvolvidos.

Desde então, o termo desenvolvimento passa a ser adotado como referência para a economia e a sociedade dos países do Norte Global - sempre associado à noção de superioridade, riqueza e soberania -, e o subdesenvolvimento, por sua vez, relacionado aos países que estão em busca do tão almejado caminho do crescimento infinito. O termo permanece, até hoje, associado à ideia de inferioridade, pobreza e dependência.

Se o desenvolvimento nos remete à noção de crescimento e riqueza e o subdesenvolvimento à ideia de inferioridade e pobreza, então há uma contradição a ser esclarecida: os países considerados subdesenvolvidos são, via de regra, aqueles que concentram a maior quantidade de riquezas naturais. Segundo Acosta (2018, p. 47), "experiências acumuladas permitem afirmar que a pobreza em muitos países do mundo está relacionada com a existência de uma significativa riqueza em recursos naturais". É o que o autor nomeia por "paradoxo da abundância", ou seja, os países que detém as maiores riquezas naturais geralmente encontram maiores dificuldades para se desenvolver e permanecem "condenados ao subdesenvolvimento", como se fosse uma "maldição dos recursos naturais" (ACOSTA, 2018, p.48).

Eduardo Gudynas (2009) nomeia por "fatalismo tropical" o destino dos países cujas economias são dependentes da extração de petróleo e de minerais, e que estão geograficamente localizados próximos à linha do Equador. Para ele, há um certo

\footnotetext{
${ }^{15}$ Naquela ocasião, Truman anuncia os quatro pontos que deveriam nortear a política externa dos Estados Unidos. O primeiro fazia referência ao seu empenho no fortalecimento da democracia no mundo; o segundo dizia respeito à reconstrução econômica dos países afetados pela Guerra, especialmente a Europa; o terceiro era o fortalecimento das nações amantes da paz contra eventuais agressores; e o quarto ponto, por sua vez, é onde Truman menciona o termo subdesenvolvimento para nomear os países de vida econômica "primitiva e estagnada" e cuja pobreza "é um obstáculo e uma ameaça a eles próprios e às áreas mais próximas". Para ele, era importante estender a essas nações a ajuda dos EUA na forma de "benefícios de nosso avanço científico e progresso econômico" (TRUMAN, 1949 apud ALCADIPANI; BERTERO, 2012, p.287).
} 
determinismo geográfico do subdesenvolvimento: "os países mais ricos em recursos naturais e mais próximos ao Equador [...] parecem destinados à pobreza" (GUDYNAS, 2009, apud. ACOSTA, 2018, p.48). Ainda segundo o autor, essa é uma visão do próprio Banco Interamericano de Desenvolvimento (BID), que reconhece a relação entre a riqueza de recursos naturais de um país e a dificuldade em se alcançar o desenvolvimento e, consequentemente, a uma intensificação das desigualdades internas (GUDYNAS, 2009).

A resposta a essa contradição tem sido sustentada e defendida por alguns grupos (inclusive o próprio BID) a partir da intensificação da extração dessas riquezas, por exemplo, com a Economia de Escala:

À medida que a produção aumenta, a utilização de insumos não aumenta na mesma proporção. Desta forma, a quantidade empregada de insumos por unidade de produto é menor quanto maior o nível de produção. À medida que quantidades maiores são produzidas, é possível otimizar a utilização dos insumos de forma que os custos por unidade se tornem decrescentes (GOMIDE et al, 2018, p.101).

Outra justificativa para se intensificar a exploração dos recursos naturais como alternativa econômica está fundamentada no discurso da ampliação das ofertas de trabalho e no aumento da arrecadação de impostos. Nesse sentido, são adotadas medidas neoliberais tais como abertura para o capital estrangeiro interessado na exploração, bem como flexibilização das legislações ambientais e das leis trabalhistas para facilitar e maximizar os lucros das empresas extrativistas. O Projeto de Lei do Senado 168/2018, de autoria do senador Acir Gurgacz (PDT de Rondônia), é um bom exemplo na medida que sintetiza diferentes propostas de flexibilização nos procedimentos de licenciamento, como o chamado "licenciamento flex", proposto pela Frente Parlamentar Agropecuária, e o PLS 654/2015, de autoria de Romero Jucá (MDB - RR), conhecido como "licenciamento a jato". Da proposta original, permanece no PLS 168/2018 ${ }^{16}$ a possibilidade de cada estado ou município estabelecer os parâmetros para licenciamento no seu próprio território, o que pode gerar um afrouxamento generalizado dos critérios de aprovação, a fim de favorecer os interesses de cada governante. O Projeto de Lei também altera as instâncias de análise, retirando da Funai, do IPHAN e do ICMBio o poder de proibir empreendimentos em áreas protegidas e em terras indígenas homologadas. Do licenciamento a jato, herda a possibilidade do empreendimento ser incluído em uma espécie de fila rápida de interesse especial do Presidente da República ${ }^{17}$.

\footnotetext{
${ }^{16}$ Apresentado ao Plenário do Senado Federal e recebido pela Comissão de Constituição, Justiça e Cidadania em 10/04/2018. Atualmente em tramitação, redistribuído ao Senador Sérgio Petecão (PSD), para emitir relatório. Fonte: https://www25.senado.leg.br/web/atividade/materias/-/materia/132865

17 Interpretação da lei feita pelo Observatório do Clima, disponível em http://www.observatoriodoclima.eco.br/projeto-senado-completa-cerco-ao-licenciamento-ambiental/
} 
Essa autonomia na interpretação e na condução dos licenciamentos minerários pode ter impactos imensuráveis, pois os estados cuja economia se sustenta na mineração podem orientar procedimentos e privilégios justificados pelo desenvolvimento. Recentemente, em função da suspensão de algumas atividades de extração mineral no estado ${ }^{18}$, a Federação das Indústrias do Estado de Minas Gerais (FIEMG) lançou uma campanha voltada para a retomada dessas atividades, justificada exatamente por argumentos como geração de emprego e de recursos para o Estado:

Minas Gerais está unida para defender seus interesses legítimos e superar o cenário de caos no campo da economia e do desenvolvimento social, potencializado negativamente pela paralisação parcial da mineração no estado [...] Tudo que esses projetos mais precisam é de atenção prioritária, no sentido de estruturar propostas de concessão à iniciativa privada - rodovias, por exemplo -, liberação de empréstimos e licenciamentos eventualmente necessários ${ }^{19}$.

Nesse discurso, a mineração é vista como a única saída para a economia do Estado e, consequentemente, para o desenvolvimento social. Manifesta-se, abertamente, a necessidade de facilitações à iniciativa privada, justificadas pelo discurso de serem benefícios que serão compartilhados com toda a população. O tom de otimismo econômico confunde consumismo com qualidade de vida e declara que a única solução é o "Pacto por Minas", com forte apelo regionalista. Em suma, a saída continua sendo a reprimarização da economia - extrativismo como promessa de crescimento para o Estado de Minas Gerais.

\subsection{EXTRATIVISMO COMO SINÔNIMO DE DESENVOLVIMENTO}

O discurso do desenvolvimento, como visto acima, tem no extrativismo uma das alternativas mais entusiasmadas para o crescimento dos países que detém reservas naturais, e está sustentado por uma perspectiva que tem a natureza como elemento à disposição absoluta dos seres humanos e, por isso, deve ser submetida e explorada a fim de garantir o pleno desenvolvimento dessas nações.

O termo extrativismo, segundo definição de alguns dicionários da língua portuguesa, está associado a qualquer atividade de retirada ou coleta de bens naturais para consumo pessoal ou mesmo para fins comerciais e industriais, sem qualquer distinção entre as práticas de extração moderadas e de baixo impacto e aquelas cuja extensão abrange grandes regiões com repercussão para além do âmbito local. $\mathrm{O}$ extrativismo pode estar relacionado à recursos

\footnotetext{
${ }^{18}$ Em decorrência dos impactos provocados pelas tragédias/crimes em Mariana (2015) e Brumadinho (2019).

19 "Palavras do Presidente". Disponível em: https://www.emfrenteminas.com.br/ Acesso em 11 Mai. 2019
} 
de origem animal (peles, carne, óleos), mineral (ouro, minério de ferro, nióbio) ou vegetal (madeiras, folhas, soja etc.).

Segundo o dicionário crítico da mineração (GOMIDE et al., 2018, p. 113-114), existem dois significados para extrativismo: o primeiro, mais orientado para o caráter econômico dessa atividade, está associado às práticas que compreendem "extração de grande volume de recursos naturais que, em sua maior parte, são exportados em sua forma mais simples (matérias-primas), ou seja, com valor agregado mínimo" para os países produtores. A segunda, por outro lado, está mais alinhada com as definições dos dicionários da língua portuguesa e significa "atividade em nível local que consiste na extração/cultivo de bens naturais. [...] e pode significar coleta de qualquer produto natural, tais como sementes, frutas, verduras, castanhas, troncos e cascas, ervas, raízes, folhas, algas, fungos etc.". Ainda segundo os autores, em geral, se trata de "atividades auto sustentáveis através das quais comunidades retiram do ecossistema aquilo que necessitam sem colocar em risco este mesmo ecossistema". Inclusive, para essas práticas, o governo federal reserva áreas específicas - Reservas Extrativistas (Resex), a fim de garantir a permanência de populações tradicionais e toda a cultura e modos de vida a elas associados (GOMIDE et al, 2018).

Predatórias ou não, geralmente as práticas extrativistas são mais intensas nos países do Sul Global, onde os recursos naturais estão mais disponíveis. Entretanto, via de regra, essas práticas são ditadas pelas metrópoles mundiais (centros do capitalismo), justificadas pelo desenvolvimento e bem-estar de todos os envolvidos - explorados e exploradores -, num sistema de dependência forçada que se mantém praticamente inalterado ao longo dos últimos séculos.

Para Svampa (2012), está em curso um processo de hibridização da economia nesses países: à financeirização e privatização estabelecidos pelo Consenso de Washington somouse, na primeira década dos anos 2000, uma nova ordem econômica e política baseada na exportação de bens primários (commodities) em grande escala, à qual ela denomina por Consenso de los Commodities. Segundo a autora, a diferença em relação aos ciclos minerários anteriores está, dentre outros fatores, na mudança do padrão de acumulação baseado na financeirização e privatização para um modelo que inclui também a expansão de grandes projetos que tendem "al control, extracción y exportación de bienes naturales, sin mayor valor agregado" (SVAMPA, 2012, p.16). Para a socióloga, o alto preço dessas matérias primas e as crescentes demandas por bens de consumo por parte dos países centrais e das potências emergentes (China, principalmente) exerceram grande influência na consolidação 
dessa nova ordem econômica e política que tem como consequência um intenso processo de reprimarização ${ }^{20}$ das economias latino-americanas (SVAMPA, 2012).

Segundo o Plano Nacional de Mineração 2030 (BRASIL, 2011, p.12), no que se refere às exportações, entre os anos de 1996 e 2008, "houve forte crescimento dos bens primários (15,2\% ao ano) em comparação com os manufaturados (7,4\% ao ano), e a taxa da importação de manufaturados cresceu em média 12,4\% ao ano, bem superior à taxa de exportação". Ainda segundo o mesmo documento, a queda nos indicadores da indústria de transformação em relação ao crescimento dos números relativos ao extrativismo mineral nesse período tem implicações,

[...] tanto para o processo de industrialização brasileira, quanto para a geração de emprego e renda, resultando em perdas de oportunidades relevantes para a economia nacional, uma vez que o volume e a qualidade de empregos gerados na etapa extrativa são muito inferiores aos gerados nas etapas de transformação (BRASIL, 2011, p.12).

Esta situação mais favorável dos países importadores em relação ao Brasil não faz parte apenas da história mais recente. A acumulação extrativista teve papel fundamental na criação das condições necessárias ao capitalismo industrial nos séculos XVIII e XIX e, desde então, tem sistematicamente beneficiado o lucro para os países importadores ao mesmo tempo que tem demonstrado ser bastante impactante para aqueles que exportam seus bens primários (ACOSTA, 2018). Isto torna evidente o fato de que o desenvolvimento não é para todos, e que o atual modelo de base extrativista acentua e reforça a divisão desigual do trabalho e dos lucros, com resultados bem diferentes nas escalas global e local.

A fim de associar as práticas extrativistas à produção industrial, o lobby do extrativismo mineral insiste em utilizar expressões como "indústria da mineração" ou "produção mineral", beneficiando-se do significado atribuído à este termo na economia dos países subdesenvolvidos e invisibilizando a realidade que vai justamente na contramão desse entendimento, como já discutido anteriormente neste trabalho. Ademais, o termo produção também remete ao processo de agregação de valor, que não ocorre na exportação do minério (commodities), pois não há transformação dos bens primários. Além dos aspectos econômicos, Milanez (2017) destaca, sobre o Plano Nacional de Mineração 2030, que a ideia da mina como uma fábrica remete a

[...] uma fonte pontual de poluição, cujos impactos poderiam ser mitigados a partir das práticas comuns de gestão ambiental, baseadas no gerenciamento de resíduos ou no aumento da eficiência. Dentro dessa perspectiva, qualquer evento de poluição ou dano

\footnotetext{
${ }^{20}$ Primazia da exportação de produtos com baixo valor agregado (ZHOURI et. al, 2016).
} 
ambiental seria resultado de uma má prática, e não um elemento inerente ao processo

de extração mineral (MILANEZ, 2017, p.94).

Milanez (2017) aponta também para a limitação desta narrativa, como se o impacto estivesse associado à execução da atividade, quando na realidade tratamos de danos e perdas irreversíveis nos ecossistemas, ao que Gudynas (2015) nominou por "amputações ecológicas".

Antonelli nos fala sobre uma colonização discursiva, empreendida desde o final dos anos 90, que tem "eficácia pragmática e simbólica, isto é, jurídico normativa, epistêmica e cultural" (ANTONELLI, 2014, p.73). Para a autora, o consenso sobre o extrativismo é construído pelas corporações e Estados, impondo uma agenda transnacional de desenvolvimento, tal como mencionado acima no "Plano de Investimentos - Pacto por Minas", resultado de uma parceria entre o Estado de Minas Gerais e o setor produtivo privado. As novas palavras de poder possibilitam que os setores financeiro, político e midiático intervenham em diferentes escalas na opinião pública e imponham sua ideologia, mascarando o que são afirmações ideologicamente marcadas (DURAND, 2007).

Para Gudynas (2015), o extrativismo está associado às atividades de extração em grande volume e intensidade, cujos recursos naturais são apropriados majoritariamente para exportação em sua forma mais simples - bens primários -, ou seja, não são processados industrialmente em território nacional, nem destinados ao mercado local. Em síntese, não geram excedentes nem agregam valor. Para o autor, o impacto do extrativismo vai além das perdas econômicas imediatas, implicando também no que ele denomina por efectos derrame.

\subsection{EFECTOS DERRAME E SUAS CATEGORIAS}

Os efectos derrame, segundo Gudynas, referem-se às repercussões que não são identificadas no nível local, ou seja, são efeitos que estão além da contaminação, do desmatamento e das relações assimétricas de trabalho geralmente reconhecidos nos projetos que incluem a extração de recursos naturais. A flexibilização de leis ambientais, a violação de direitos e a dependência econômica, podem ser compreendidos como alguns dos exemplos desses efeitos, assim chamados pois transbordam para além do local (ou entorno mais imediato) da extração. Podem ter início com um determinado empreendimento, mas acabam por ter efeitos duradouros e extensos sobre o território e sobre as populações, afetando-os de diversas formas (ou em diferentes categorias) (GUDYNAS, 2018). Para o autor, dentre essas categorias pode-se identificar as de caráter ambiental, territorial, social e econômico (GUDYNAS, 2015). Vale ressaltar o aspecto multidimensional desses efeitos, pois podem ser 
potencializados na medida que se associam. Na categoria ambiental, por exemplo, o autor destaca dois tipos de derrame: um que se refere à mercantilização da natureza e outro à flexibilização das leis ambientais ${ }^{21}$. O primeiro alinha-se a já citada visão antropocêntrica da natureza, ou seja, como algo passível de apropriação, transformação e mercantilização na medida dos interesses do ser humano. O segundo, por sua vez, trata da diminuição de exigências ambientais, tornando mais fáceis os trâmites para aprovação dos empreendimentos extrativos. Gudynas (2015) faz um alerta sobre os impactos perversos dessa flexibilização sobre todo o sistema normativo e também sobre a institucionalidade ambiental do país, uma vez que essas concessões tendem a abrir espaços cada vez maiores justificados pela necessidade de acelerar processos e descomplicar a gestão. Ou seja, o efecto derrame, neste caso, vai além do impacto ambiental no território explorado e alcança outras esferas, ampliando as consequências negativas dessas práticas.

O avanço do extrativismo requer, cada vez mais, outras territorialidades, caracterizadas como efeitos territoriais por Gudynas (2015). Impostas pelos empreendimentos, essas demandas se estendem e se sobrepõem, via de regra, sobre outras preexistentes, como as indígenas, camponesas ou áreas institucionalizadas de preservação ambiental, anulando-as ou debilitando-as. O impacto, portanto, se dá para além do território, pois acaba por extinguir ou mesmo submeter, determinadas culturas tradicionais, além de consumir as reservas de áreas ambientais que impactam a vida de todos os cidadãos (água, oxigênio, clima etc).

Similar aos derrames ambientais, os efeitos sociais repercutem na qualidade de vida e na segurança dos cidadãos. No amplo leque de violações dos direitos humanos, o autor cita o descumprimento das obrigações de garantir a participação social, a omissão ou falta de transparência de informações para a população envolvida, o despejo forçado de comunidades, a criminalização de protestos, o assassinato de manifestantes e de lideranças, dentre outros. A respeito de tais violações Gudynas (2015) usa o termo extrahección (uma sobrecarga), para nomear o extrativismo que utiliza da violência em suas estratégias para alcançar os fins desejados. Atualmente, este modelo tem se tornado, cada vez mais, a forma usual de apropriação da natureza pois, se os processos de licenciamento ambiental, de informação às comunidades e de contabilização dos custos ocultos fossem efetivamente considerados, os empreendimentos dificilmente seriam aprovados. $\mathrm{O}$ autor também faz menção às recorrentes ilegalidades identificadas ao longo desses processos, tais como a corrupção e as

${ }^{21}$ O PLS 167/2018 citado anteriormente é um exemplo claro da flexibilização ambiental em benefício das práticas extrativistas. 
"alegalidades", definida por ele como posturas que não são ilegais, mas que se aproveitam de vazios e entrelinhas nas leis e objetivamente vão contra o espírito do marco jurídico.

No que diz respeito aos efeitos econômicos, os impactos ficam por conta da dependência em relação à exportação de matéria prima. $\mathrm{O}$ extrativismo também cria ilhas econômicas alinhadas estritamente com os interesses da economia global, ou seja, porções do território nacional com poucos vínculos e preocupações em relação às comunidades onde estão implantados. A tecnologia utilizada, bem como parte significativa do corpo técnico, é importada e sem que haja real capacitação ou aprimoramento da mão de obra local, ficando o grosso dos ganhos concentrados nas matrizes, que geralmente estão sediadas em países do norte global.

\title{
3 MINAS GERAIS E OS EFEITOS DERRAME DO EXTRATIVISMO
}

\section{MINERAL}

A história da região onde hoje se encontra o Estado de Minas Gerais está marcada, desde seu nome, pelo extrativismo mineral. Sob a perspectiva do Estado, esse é um privilégio a ser exaltado, especialmente nos números expressivos como a região contribui para o quadro da produção mineral nacional. Segundo o site da Companhia de Desenvolvimento do Estado de Minas Gerais (CODEMIG) ${ }^{22}$ :

\begin{abstract}
A história e as tradições de Minas Gerais estão fortemente ligadas à atividade mineradora e às suas reservas minerais. Afinal, o Estado extrai mais de 160 milhões de toneladas de minério de ferro por ano e responde por $29 \%$ de toda a produção mineral do país, por $53 \%$ da produção de minerais metálicos e por cerca de $50 \%$ de todo o ouro produzido no Brasil.
\end{abstract}

Entretanto, se esses dados demonstram o volume das riquezas naturais do Estado os fatos recentes também evidenciam os ônus decorrentes dessa tradição extrativista. $O$ rompimento das barragens de resíduos minerários em Mariana e Brumadinho (além das diversas ameaças de rompimento que rondam alguns municípios mineiros atualmente), demonstram que uma outra perspectiva sobre as atividades minerárias no Estado precisa ser colocada em maior evidência. Há que se contabilizar, além dos impactos diretos dessas últimas tragédias ambientais, aqueles apontados por Gudynas como 'efeitos derrame'.

Desde os séculos XVII e XVIII, a exploração dos recursos minerais tem orientado a fundação e a história de boa parte dos arraiais que mais tarde se tornariam algumas das cidades e capitais $^{23}$ das Minas Gerais. Assim, desde as suas origens, a região tem no

\footnotetext{
${ }^{22}$ Disponível em: http://www.codemig.com.br/atuacao/mineracao/. Acesso em 08 Mai. 2019.

${ }^{23}$ As cidades de Mariana e de Ouro Preto, ambas fundadas a partir da exploração do ouro no século XVII, foram, respectivamente, a primeira e a segunda capital do Estado.
} 
extrativismo não apenas os fundamentos de boa parte de sua economia, mas também as bases da determinação geográfica dos seus primeiros núcleos urbanos e, consequentemente, dos processos migratórios e da estrutura social daí decorrente. Temos uma sociedade minerária, por assim dizer, constituída a partir da naturalização do extrativismo em nossos territórios e, talvez por isso, alheia, até bem pouco tempo, aos impactos e custos decorrentes desses processos em nosso dia-a-dia. Em síntese, nós mineiros somos todos atingidos pela mineração, de forma direta ou por seus efectos derrame, mesmo que pouco conscientes disso.

Se o extrativismo determinou ciclos de abundância para a metrópole portuguesa, parte da população local também se beneficiou dessas práticas, inclusive constituindo uma sociedade bem peculiar nos tempos da colônia (mineradores, escravos alforriados, imigrantes e comerciantes locais). A substituição do poder direto da Igreja pelas Ordens Terceiras também foi determinante não apenas na conformação do território (edificando a maior parte da nossa arquitetura religiosa e respectivas freguesias) mas, principalmente, na consolidação dessa sociedade, favorecida por um ambiente de maior autonomia em relação às demais regiões do país, e pela circulação de excedentes propiciados pela mineração.

Mas não foi assim em todos os núcleos. Alguns arraiais situados na Comarca de Sabarabuçu e que hoje conformam alguns municípios do vetor sul da Região Metropolitana de Belo Horizonte (RMBH), guardam outros registros dos períodos de extração de ouro nas Minas Gerais. É o caso de Raposos, pequeno município a $30 \mathrm{~km}$ de Belo Horizonte, onde não se identifica, como em Ouro Preto ou Mariana, as marcas dos excedentes da mineração na exuberância dos grandes sobrados ou na arquitetura religiosa barroca. Ali permanecem os registros do grande número de viúvas de trabalhadores da mineração na cor púrpura de sua bandeira, assim como da presença da classe operária no casario deixado pelas companhias mineradoras, e que hoje domina a paisagem local.

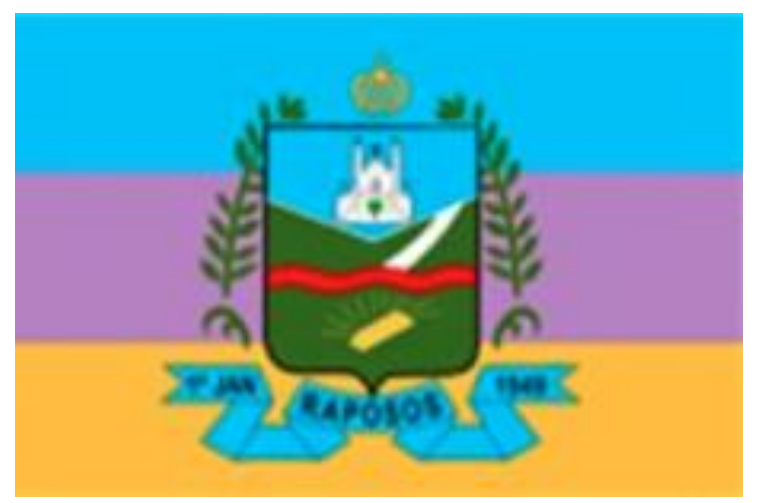

Figura 02: Bandeira do município de Raposos

Fonte: Fonte: site da Prefeitura Municipal de Raposos- Disponível em: http://www.raposos.mg.gov.br/detalhe-da-materia/info/simbolos-e-hino-da-cidade/6487 


\subsection{INTRODUÇÃO OU PEQUENO HISTÓRICO DE RAPOSOS}

A história da cidade de Raposos está vinculada à atividade mineradora desde a chegada dos bandeirantes paulistas à região, que se deu por volta de 1690. De acordo com Oliveira Gomes (1996), o bandeirante Pedro de Morais Rapôso estabeleceu seu acampamento na confluência do Rio das Velhas (conhecido na época como Rio Guaicuy) com o Ribeirão da Prata, dando início ao arraial que posteriormente seria conhecido por Arraial dos Rapôsos, em sua homenagem . Como era de costume, ali edificaram um templo que foi consagrado à Nossa Senhora da Conceição, padroeira do dia 08 de dezembro, data marcada como fundação do município. Esta edificação é reconhecida, desde 1824, como sendo a primeira matriz de Minas Gerais sem, contudo, guardar registros em seus altares da abundância dos períodos de extração de ouro naquele local ${ }^{24}$.

Desde então, Raposos vem contabilizando em sua história números expressivos referentes à extração de seus recursos naturais, mas também outros tantos que representam o impacto, ou melhor, os efectos derrame dessas práticas sobre seu território e também sobre sua população. Já na chegada dos bandeirantes, no final do século XVII, é possível identificar alguns desses efeitos sobre o território, decorrentes da forma violenta como os povos indígenas que ali viviam foram expulsos sem que registros de seus hábitos e tradições fossem preservados, apesar da região ser conhecida na época por Minas dos Cataguás, justamente pela importância e expressividade dessas comunidades naquele local. Os povos nativos não são reconhecidos como agentes na formação sociocultural local, assim como não há registros de sua resistência e luta (RESENDE; LANGFUR, 2007), sintetizando o que poderíamos nomear por efeitos derrame de caráter cultural e social. Um dos efeitos dessa desterritorialização foi a naturalização do extrativismo na região.

Pode-se afirmar que até hoje o município padece desses efeitos sobre o território, pois a maior parte das terras pertence à empresa de mineração AngloGold Ashanti ${ }^{25}$ que perpetua o domínio do capital estrangeiro nas práticas extrativistas da região. Beneficiados pela Constituição de 1891 que vinculava o direito de propriedade com o de exploração do subsolo, os ingleses acabaram por adquirir boa parte das áreas circunscritas no Quadrilátero

\footnotetext{
${ }^{24}$ Os fatos históricos específicos sobre Raposos são escassos, e resultam de contribuições de alguns moradores, dentre eles o jornalista Jurandir Persichini e o Sr. João Oliveira Gomes, que coletaram informações de documentos e depoimentos orais durante as últimas décadas do século XX, na tentativa de registrar a história da cidade.

${ }^{25}$ A antiga mineradora Saint John Del Rey Minig Company, após várias conformações societárias, está configurada atualmente como a companhia AngloGold Ashanti, com sede na África do Sul. Segundo o site da Associação Brasileira de Comunicação Empresarial (ABERJE), é uma das maiores produtoras de ouro do mundo, com operações em 9 países. As três unidades operacionais da empresa em território nacional (duas delas no Quadrilátero Ferrífero) são responsáveis por 15\% de toda a produção de ouro do grupo no mundo.
} 
Ferrífero, e até hoje detém grandes propriedades em vários municípios, especialmente em Raposos. Isto tem sido relevante para a gestão municipal, pois limita a ação do poder público em relação às políticas territoriais, dificultando a autonomia do município quanto ao planejamento urbano - áreas de expansão, de equipamentos urbanos, de políticas de habitação, dentre outros. Enfim, qualquer ação nesse sentido está subordinada à boa vontade da mineradora, que já anuncia em seu site a intenção de investir no mercado imobiliário com o banco de terras que acumulou ${ }^{26}$.

Além desse efeito direto sobre a organização do território raposense, a prática do extrativismo também deixou uma marca de grandes proporções, identificada por Gudynas (2015) como efeito derrame econômico. No final do século XVII, o ouro em aluvião é esgotado e a economia de grande parte das Minas Gerais entra em colapso. A partir daí, as atividades de mineração foram abandonadas e muitas famílias deixaram a região de Raposos em busca de outros locais que oferecessem melhores oportunidades, já que muito pouco se acumulara nas fases mais prósperas:

\begin{abstract}
Os recursos necessários para restaurar a mineração e reorganizá-la sobre as novas bases que a situação impunha, tinham se volatizado, através do oneroso sistema fiscal vigente, no fausto da corte portuguesa e na sua dispendiosa e ineficiente administração" (PRADO Jr, 1984, p.62).
\end{abstract}

Com o declínio desse ciclo de mineração e a independência do país em 1822, o processo de abertura do Brasil aos investimentos dos países estrangeiros ${ }^{27}$ interessados em explorar os recursos minerários do subsolo se tornou uma ótima oportunidade. Algumas empresas europeias, sobretudo os investidores britânicos, eram os mais interessados e dispunham de capital e tecnologia necessários para desenvolver tal atividade (ALVES, 2015).

A partir daí, ocorre um novo ciclo de produção aurífera em Minas Gerais, e a região de Raposos (ainda parte integrante do território que compreendia o extenso município de Sabarabuçu), rica em ouro subterrâneo, entra numa nova fase de exploração mineral com a chegada da empresa inglesa Saint John Del Rey Mining Company ${ }^{28}$, em 1832. Muito próspera em suas atividades de extração na região, a mineradora utilizou a mão-de-obra escravizada até

\footnotetext{
${ }^{26}$ Ver site da empresa. Disponível em: https://www3.anglogoldashanti.com.br/negocios/Paginas/default.aspx

${ }^{27}$ Portugal aumentou seu grau de dependência em relação à Inglaterra desde a assinatura do Tratado de Methuen (1703), favorecendo amplamente a Inglaterra no comércio entre os dois países. Com a proclamação da independência, em 1822, essas relações se intensificam e as companhias mineradoras veem no Brasil uma ótima oportunidade de investimento, tendo em vista as grandes reservas naturais ainda inexploradas por falta de tecnologia.

${ }^{28}$ Ao longo de sua história, devido à mudanças societárias e de administração, a empresa também foi nomeada Mineração Morro Velho S.A. e, hoje em dia, recebe o nome de AngloGold Ashanti.
} 
1886, quando houve um grave acidente, provocando o fechamento da mina ${ }^{29}$. Nessa época, a empresa tinha, entre os seus 2.500 trabalhadores, 1.690 pessoas escravizadas. A retomada das atividades minerárias pela empresa britânica se dá em 1890, sob o nome de Mineração Morro Velho, ocasião que os ingleses passam a contratar mão de obra livre para as minas tornandose, desde então, a maior geradora de empregos da região (GROSSI, 1981).

Raposos teve, durante todo esse período (do século XIX até o final dos anos 1990), sua economia extremamente dependente da mineração, com a maior parte da população local trabalhando nessa atividade, seja de forma direta (como empregados da empresa), seja como prestadores de serviço ou mesmo no comércio que atendia a essas famílias. Com o encerramento das atividades na mina de Raposos no ano de 1998, a cidade teve uma redução significativa em sua arrecadação, impactando de forma muito intensa a economia local ${ }^{30}$.

Além dos efeitos decorrente das péssimas condições de trabalho nas minas, deixando números expressivos de óbitos entre os trabalhadores e, consequentemente muitas famílias órfãs, outro exemplo de derrame social importante foi a forte repressão, por parte da empresa, contra o movimento sindical. Organizados pela primeira vez em 1920, os trabalhadores da Mineração Morro Velho sofreram punições que implicaram na demissão dos líderes sindicais, bem como na denúncia de vários trabalhadores ao governo como comunistas (durante a era Vargas). Além disso, subir de cargo na empresa era quase impossível, pois os postos mais altos e mais bem remunerados eram geralmente ocupados pelos técnicos estrangeiros ou pessoas com formação técnica ou superior, provenientes de outras regiões (GROSSI, 1981).

Essa hierarquia se refletia não apenas nas condições de trabalho, mas também nas moradias e modos de vida da cidade. Ao se instalarem no Brasil, as empresas inglesas implementaram as company towns, vilas construídas para alojar empregados e administradores que vinham da Europa aqui trabalhar. Os ingleses tinham suas próprias festas, escolas e cemitério. Além disso, ocupavam com suas moradias de grande porte as áreas mais altas e arejadas.

\footnotetext{
${ }^{29} \mathrm{O}$ trabalho nas minas subterrâneas também envolvia o risco de desmoronamentos e inundações e dois graves acidentes marcaram a história da mina de Morro Velho. O primeiro deles ocorreu em 1867, quando um incêndio matou cerca de 21 escravos. O segundo, considerado o maior acidente já ocorrido na mina, ocorreu em 1886, quando o sistema de escoramento cedeu devido à enorme pressão exercida pela quantidade de terra e pedra, provocando o desmoronamento de toda a mina. Em decorrência deste episódio, a Mina de Morro Velho foi interditada até 1890, quando então foi reaberta (ALVES, 2015).

${ }^{30}$ Segundo dados do Plambel, em 1985, cerca de $84 \%$ do PIB do município advinha da indústria mineradora, enquanto os setores de comércio e agropecuária eram praticamente inexpressivos, e o setor de serviços contribuía com 14,56\% do PIB (PLAMBEL, 1985). Dados recentes da região apontam grande redução na atividade industrial (apenas 5,2\% no PIB municipal enquanto o setor de serviços assume papel central, com $46,5 \%$ ) (IBGE, 2012). Dessa forma, as oportunidades de emprego na região ficam limitadas a cargos públicos (setor de serviços), ao pequeno comércio local e ao trabalho informal.
} 


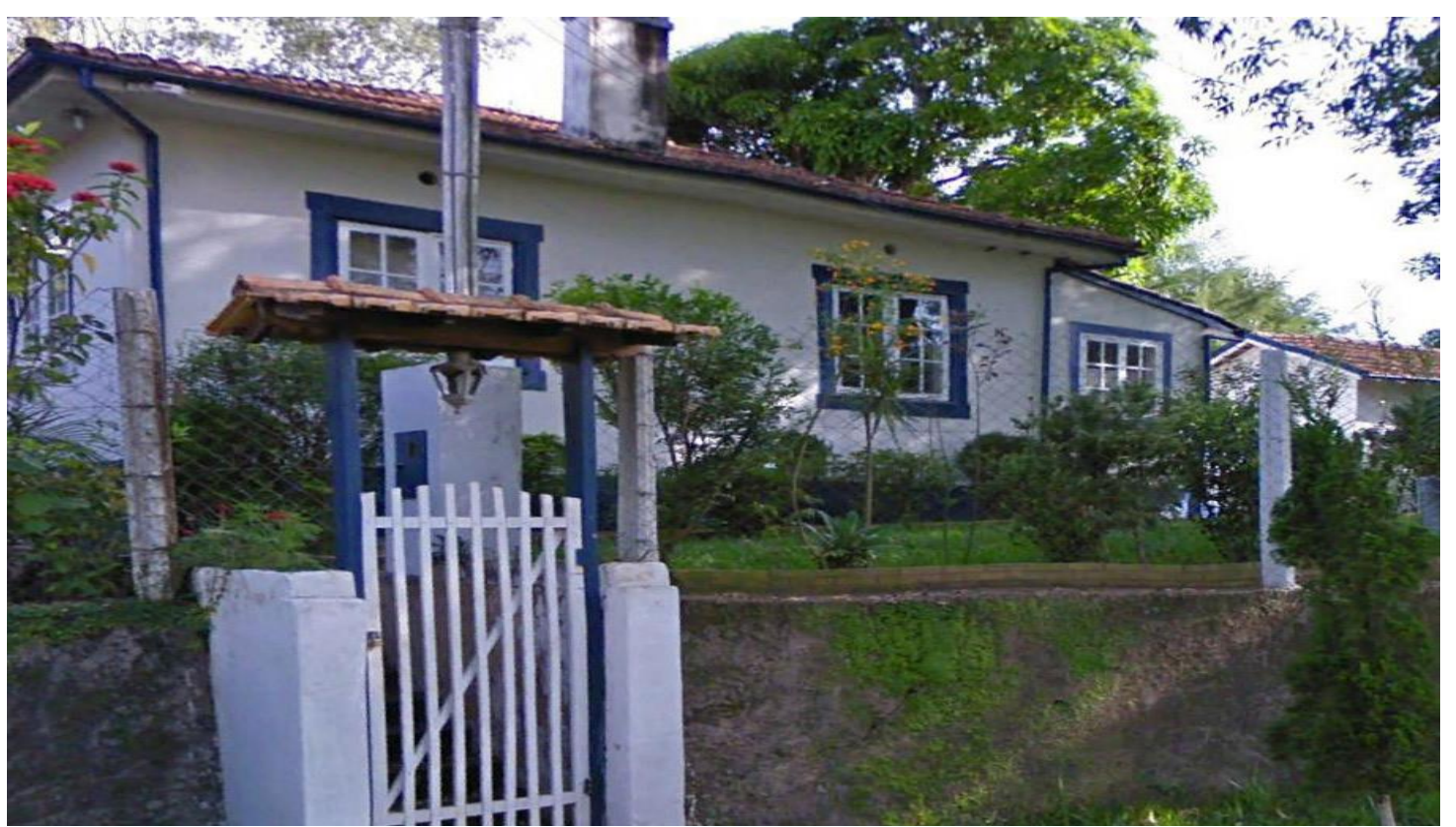

Figura 03: Casarão no bairro dos engenheiros, em Raposos.

Fonte: Acervo disciplina Planejamento Urbano, Escola de Arquitetura UFMG, 2019.

Os operários, por sua vez, permaneciam nas áreas mais baixas da cidade (sujeitas a inundações), em residências padronizadas e pequenas, dispostas lado a lado ao longo das vias, tornando a segregação social ainda mais evidente (ALVES, 2015). Este padrão de moradias ainda existe na cidade de Raposos, e pode ser facilmente reconhecido no conjunto da Várzea do Sítio, tradicional bairro operário da cidade.

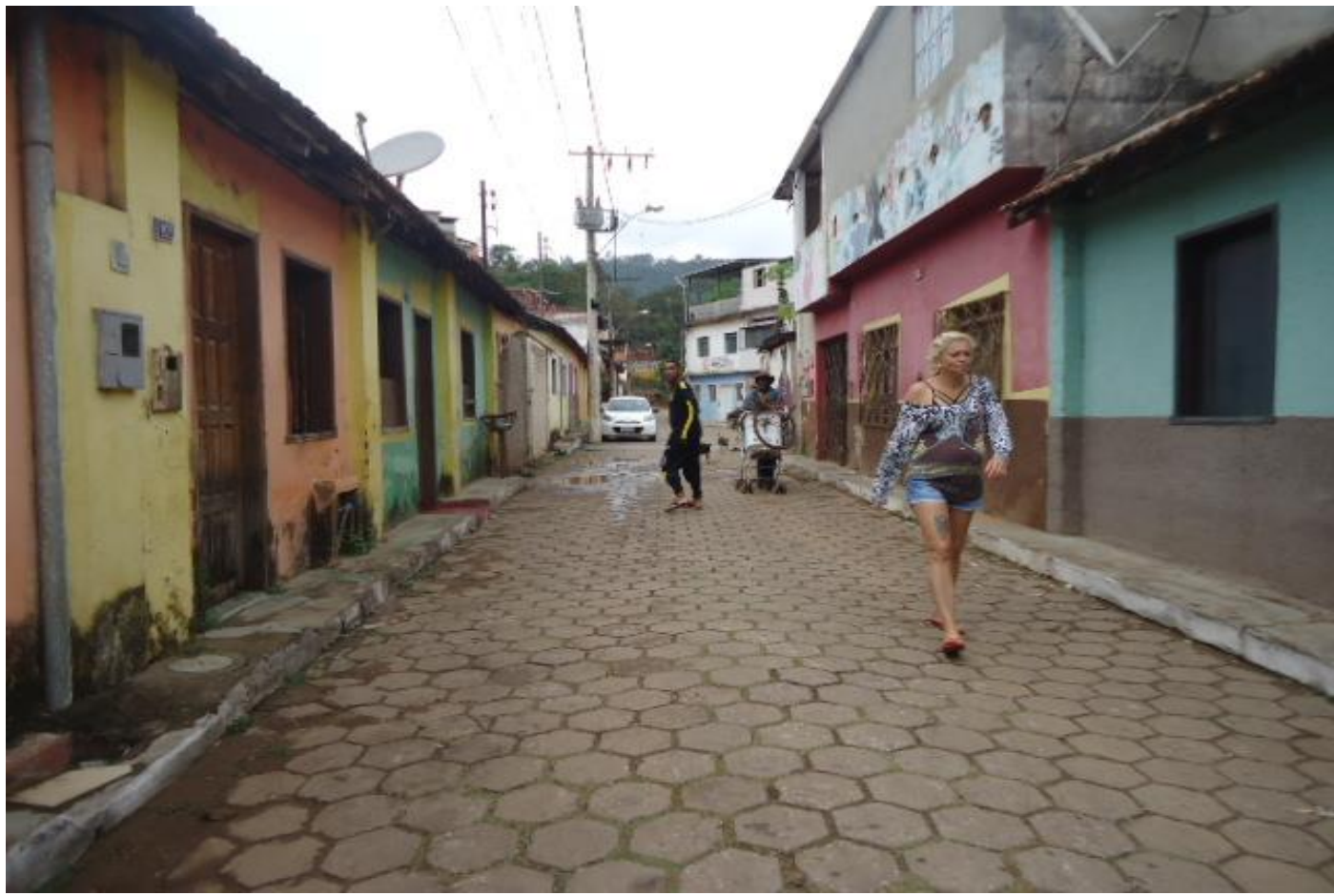

Figura 04: Rua no bairro operário da Várzea do Sítio, em Raposos Fonte: Acervo disciplina UNI-009 - Escola de Arquitetura UFMG, 2018. 
Nesse mesmo local também podem ser identificadas outras formas de efeitos derrame, pois o bairro é, ainda hoje, uma das áreas mais vulneráveis da cidade, enfrentando problemas como criminalidade e tráfico de drogas. Além disso, por sua localização próxima ao Ribeirão da Prata, carrega um histórico de recorrentes inundações e, no caso de rompimento das barragens que ameaçam atualmente o município, o local será atingido, sendo considerada uma das áreas de 'autossalvamento' pelas empresas mineradoras ${ }^{31}$, ou seja, sem garantias de socorro por parte das empresas ou do poder público.

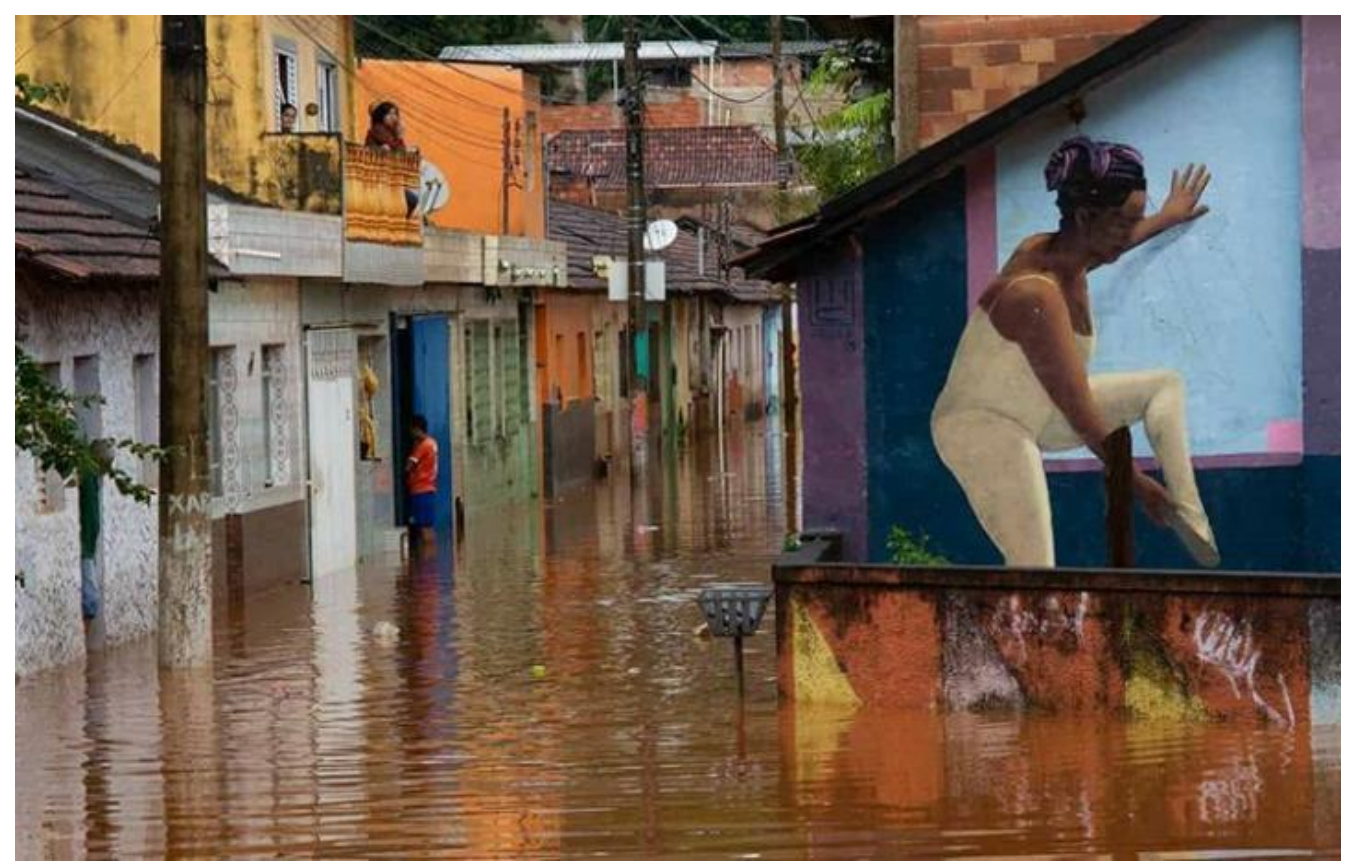

Figura 05: Inundação no bairro Várzea do Sítio, em Raposos, ocorrida após as chuvas de janeiro de 2020. Fonte: CBH Rio das Velhas/ Luciano Oliveira, 2020.

Os efectos derrame social, territorial, ambiental e econômico permanecem no município bem mais do que os registros da opulência, ainda que daquela região tenha sido extraída a maior parte do ouro das Minas Gerais e, mais recentemente, do minério de ferro.

\subsection{EFEITOS DERRAMES DO RISCO}

Desde 2016, o Laboratório de Estudos Urbanos e Metropolitanos (Lab-Urb) da Escola de Arquitetura da UFMG vem atuando em um projeto de extensão no município de Raposos - Construindo a Urbanidade Metropolitana . Desde 2017, um novo formato de trabalho tem sido construído, a partir de um edital específico da Pró-Reitoria de Extensão

\footnotetext{
${ }^{31}$ Segundo o site da Vale, a Zona de Autossalvamento (ZAS) é a "Região que está até $10 \mathrm{~km}$ ou 30 minutos do ponto de rompimento da barragem. A própria pessoa deve providenciar o seu salvamento. Ela deve sair da mancha e ir para uma zona segura por conta própria. Não há tempo para nenhum órgão publico realizar esse salvamento". Disponível em: http://www.vale.com/brasil/PT/aboutvale/servicos-para-comunidade/minasgerais/atualizacoes_brumadinho/Paginas/seguranca-de-barragens.aspx. Acesso em 30 de jan. 2020.
} 
(PROEX), cuja proposta é trabalhar, simultaneamente, "tanto como oportunidade para os alunos vivenciarem a interlocução entre a universidade e a sociedade civil a partir de ações coletivas quanto como possibilidade de integralização de créditos, ofertados na disciplina ou 'Módulo de Formação' correlato" (FERRARI et. al, 2019, p.9).

Favorecido por essa iniciativa da Universidade ${ }^{32}$ e pela parceria firmada com agentes locais $^{33}$, o grupo pode experimentar uma maior aproximação com a comunidade de Raposos permanecendo alguns períodos na cidade ${ }^{34}$. Essa modalidade de trabalho tem possibilitado diversas ações e trocas, e a cada semestre o projeto foca em um tema que seja relevante para o município.

No primeiro semestre de 2019, compartilhamos com os moradores um novo desafio. Como apresentado anteriormente, Raposos, assim como outros municípios do Quadrilátero Ferrífero, está vivendo a ameaça do rompimento de três barragens que se encontram em estado de alerta máximo. Essa experiência foi particularmente marcante para todos os envolvidos, pois quando a cidade recebeu a notícia dos riscos de rompimento a equipe de alunos e professores manteve a agenda de trabalho, acreditando que esta aproximação seria importante para ajudarmos na construção de espaços de discussão e na busca de informações.

A partir daí a rotina da cidade e da população ficou definitivamente alterada. Várias Camionetes da empresa Vale, assim como grande número de funcionários da mineradora, passaram a integrar a paisagem local seja no trânsito, nos restaurantes ou nos "pontos de encontro" que foram implantados na cidade. O risco iminente de rompimento das barragens se tornou um assunto constante entre os moradores, bem como a incerteza de cada momento seguinte. A distribuição de folhetos pela Vale também foi motivo de grande exaltação em função de informações incorretas acerca do alcance da lama tóxica no território e de alguns dos locais de encontro. Os impressos demonstravam que a empresa não tinha conhecimento

\footnotetext{
${ }^{32}$ Que contribuía na forma de bolsas de extensão para 02 alunos de graduação e ajuda de custo para cobrir parte das despesas com a alimentação dos participantes (o restante desses custos, bem como alojamento, era oferecido pelos parceiros locais). Infelizmente, desde o segundo semestre de 2019 esse edital está suspenso e a disciplina tem procurado outro formato para continuar os trabalhos na região.

${ }^{33}$ O principal parceiro do projeto em Raposos é a Casa de Gentil (Rafael Gonçalves e Glauco Gonçalves), organização da sociedade civil (OSC) sem fins lucrativos localizada na Várzea do Sítio. A Casa é um espaço que acolhe as crianças do bairro para atividades de artes e cultura em geral, expandindo os horizontes dessas crianças e jovens. Outro grande parceiro foi o Padre Eribaldo, responsável pela Paróquia Nossa Senhora da Conceição até Setembro de 2019. Sempre envolvido em muitas causas locais, foi um parceiro importante para a concretização das imersões no município

${ }^{34}$ Chamamos estes módulos nos quais os alunos permanecem na comunidade parceira de 'imersões', justamente pelo aprofundamento no cotidiano da cidade. Nesses períodos, que variam de quatro a cinco dias, as equipes se hospedam em residências cedidas pelos parceiros, de maneira a experimentar a vida local, além de criar espaços de aproximação com a população.
} 
do território, pois marcava como ponto de encontro um bairro que não existe no município bairro Varela.

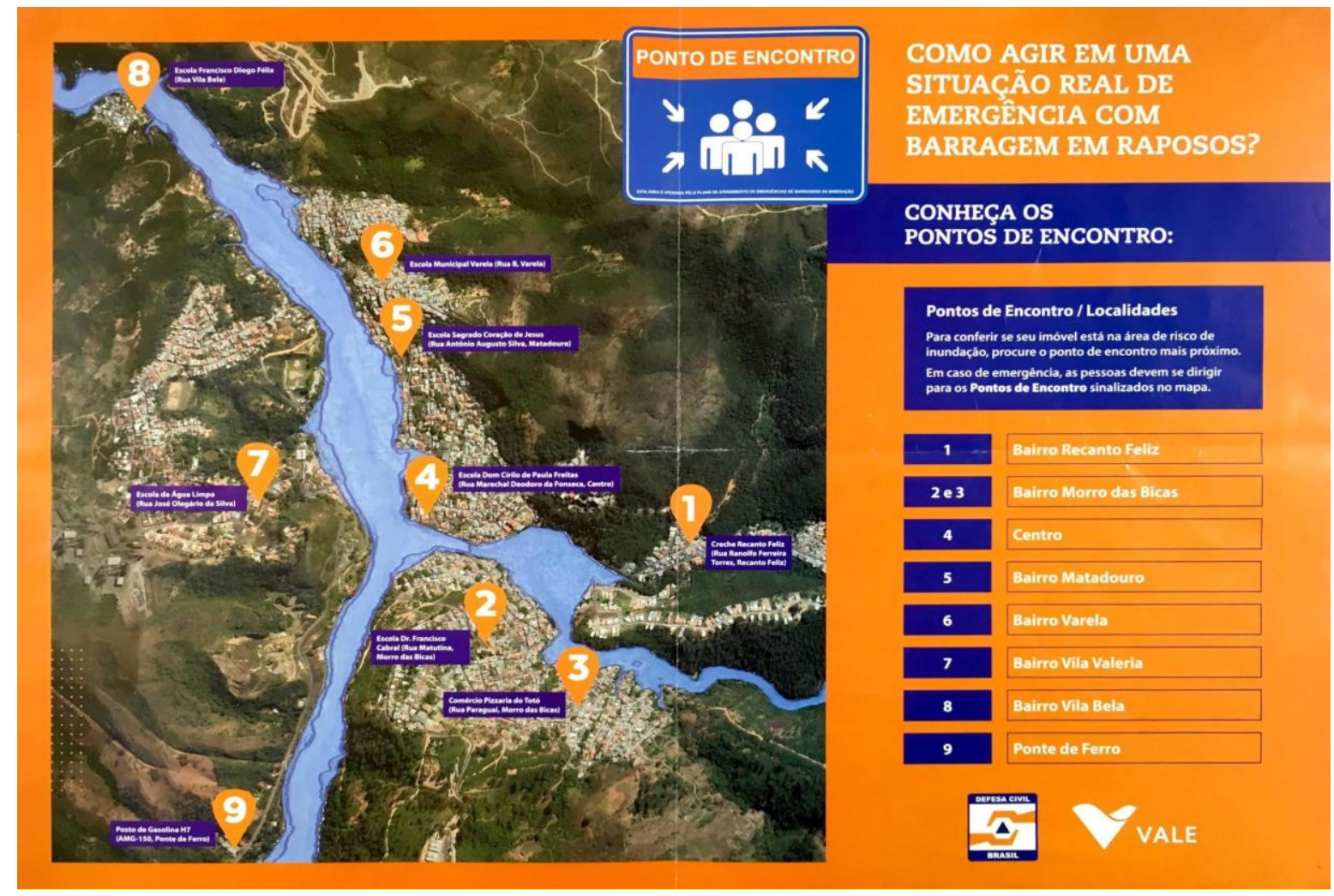

Figura 06: Flyer distribuído pela empresa Vale aos moradores de Raposos Fonte: acervo das autoras.

Além disso, a mancha de inundação pela lama estava marcada em tons de azul, levando parte da população a acreditar que seriam atingidos apenas pelas águas do rio das Velhas em mais uma de suas enchentes. Ou seja, a informação não era condizente com os reais impactos que a lama tóxica acarretaria no caso do rompimento das barragens. Outra mensagem importante dizia respeito aos pontos de encontro. Escolas anunciadas no bairro do Matadouro - Escola Varela - não existe, e a Escola Sagrado Coração de Jesus se encontra no bairro Centro. Além disso, o bairro Várzea do Sítio se encontra totalmente em Zona de autossalvamento, mas também foi anunciado como ponto de encontro no flyer abaixo. 


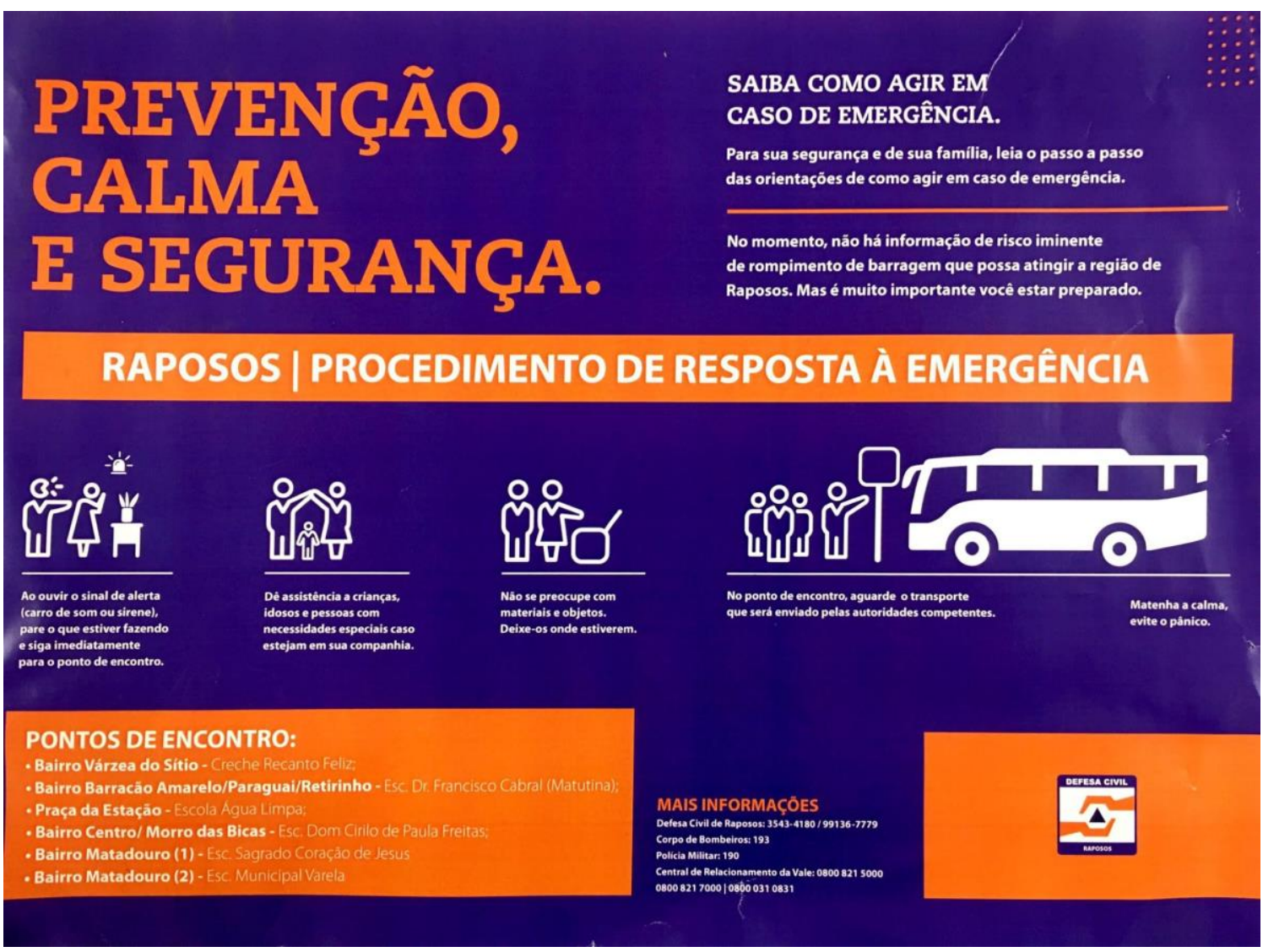

Figura 07: Flyer distribuído pela empresa Vale aos moradores de Raposos

Fonte: acervo das autoras.

O tormento, o sofrimento e o medo são, como descrito por uma moradora de Barão de Cocais $^{35}$, uma "morte a conta gotas", ou uma "antecipação da tragédia"36. Assim como em Barão de Cocais, foram instaladas também em Raposos sirenes de emergência para alertar a população no caso de rompimento. Este equipamento funciona na lógica do 'autossalvamento', pois transfere para a população a responsabilidade em relação a sua salvaguarda, uma vez que caberá ao cidadão buscar algum lugar seguro. A mesma moradora de Barão de Cocais relata que essas soluções técnicas adoecem e enlouquecem os atingidos, pois demandam um estado permanente de atenção.

\footnotetext{
${ }^{35}$ Barão de Cocais é mais um dos municípios mineiros que contabiliza os ônus da mineração. Atualmente, assim como Raposos, sofre com a ameaça de rompimento de uma barragem de rejeitos.

${ }^{36}$ Esse relato e alguns entendimentos presentes nessa parte do texto derivam do evento; "Debate UFMG - Para além do rompimento: a visão dos movimentos sociais, ambientalistas e MP”, organizado pelo Grupo de Estudos em Temáticas Ambientais (GESTA), em parceria com a Pró-reitoria de extensão da Universidade Federal de
Minas
Gerais
(UFMG)
e 0
Participa
UFMG.
Disponível
em:

https://www.youtube.com/watch?v=TXeNU9V0O1w
} 
Nos períodos que estivemos em Raposos foi possível compartilhar com a população a experiência da simulação do rompimento ${ }^{37}$. Acompanhamos a reunião preparatória realizada na Escola Dom Cirilo, ponto bem central da cidade. Durante o encontro, a Defesa Civil informou que a lama das barragens localizadas em Ouro Preto demoraria aproximadamente uma hora e meia para alcançar Raposos, mas o eventual rompimento da barragem localizada no Distrito de Macacos (Nova Lima) seria bem mais impactante pois, neste caso, a lama atingiria o município em apenas quarenta minutos, muito pouco tempo para deslocamento de idosos, enfermos ou crianças.

O alarme da Companhia Vale foi um outro ponto de tensão entre os presentes. $\mathrm{O}$ equipamento está fixado em uma camionete da empresa que será dirigida por um funcionário da Defesa Civil do município. Este, por sua vez, receberá a notícia via celular diretamente da Vale e terá a responsabilidade de correr todo o município alertando a população. No caso de alguma falha mecânica no veículo, ou mesmo de falta de bateria ou sinal de telefonia a população não receberá o sinal de alarme podendo ser surpreendida pela lama sem tempo para buscar um local seguro ${ }^{38}$. Não bastasse o quadro de violência já desenhado, a empresa pintou com tinta vermelha as calçadas que estão nas áreas de 'autossalvamento', produzindo um grande desconforto para todos que transitam cotidianamente naqueles locais. A sensação é de caminhar em área de 'morte provável', numa violência de conta gotas, como bem descreveu a moradora de Barão de Cocais.

O que mais se escutou ao longo do semestre de trabalho em Raposos foram relatos sobre a insegurança diária, a dificuldade para dormir, o medo de não ouvir o alarme e de ser surpreendido pelo rompimento. Também há a ameaça cotidiana que paira sobre sua família e amigos: como ir trabalhar ou estudar e deixar a família? Como sair para atividades cotidianas ou de lazer e deixar os amigos? A principal via de acesso a Raposos - MG-150 -, que corre paralela ao Rio das Velhas e já dentro do município, passa rente a uma outra barragem de rejeitos $^{39}$. A chegada ao município, por si só, já confere uma grande tensão aos transeuntes, pois nesse local não há como ser avisado caso aconteça algum rompimento. Isso é de uma

\footnotetext{
37 A simulação ocorreu no dia 31/03/2019 e, no mesmo dia pela manhã, foram organizadas reuniões preparatórias para explicar os procedimentos e dar algum retorno para a população sobre o que estava acontecendo. A reunião foi conduzida pela Defesa Civil do município, sem que a Vale se pronunciasse sobre os riscos, mesmo estando presente com grande número de funcionários. As questões respondidas diziam respeito apenas aos procedimentos a serem adotados no dia da simulação (dia seguinte). As demais questões (riscos reais, dimensão do impacto, para onde seriam levados, dentre outros) não foram respondidas.

${ }^{38}$ No dia da simulação, nos distribuímos pela cidade em pontos diversos e nem todos conseguiram escutar a sirene. Alguns em locais bem centrais da cidade, inclusive.

${ }^{39}$ De propriedade da Anglo Gold, esta barragem não se encontra em risco iminente de rompimento até a data de elaboração deste trabalho. Entretanto, por se tratar de rejeitos de mineração de ouro, podem ser fontes de grande contaminação ambiental (solo, cursos d’água, etc.), por causa da presença de metais pesados e arsênio.
} 
violência sem limites, especialmente porque é o único caminho para o raposense executar algumas de suas tarefas mais rotineiras, tais como ir ao trabalho, a escola ou mesmo a sua própria casa (do outro lado do rio).

Essa pressão cotidiana a que estão submetidos os moradores de Raposos, sob ameaça ou risco continuado de um rompimento que pode ou não acontecer, já é por si só um efeito de enormes proporções. A esse fenômeno nomeamos aqui por "efeito derrame do risco", por considerarmos, assim como Gudynas (2018), sua capacidade de transbordar para além dos impactos diretos da extração, com efeitos duradouros e extensos sobre o cotidiano das pessoas, afetando-as das mais diversas formas.

Entende-se aqui o risco como uma teia de incertezas, ameaças, vulnerabilidades e inseguranças, um emaranhado de sentimentos e um subproduto da modernização (BECK 2010). A exposição a essas sensações é alongada no tempo, numa experiência repetida e sistemática, e num contexto difícil de evidenciar o sofrimento e legitimá-lo como tal. Oliveira (2014) acrescenta que é complexa a identificação acerca da origem do risco, o que dificulta sua culpabilização, assim como qualquer tipo de compensação para quem o sofre.

Tal quadro de injustiça social não ocorre em casos extraordinários, por algum erro no processo ou problema de conduta. Assim como os efeitos derrame abordados anteriormente, estes fatores são contabilizados e decorrem de escolhas políticas, fazem parte do modelo de desenvolvimento alicerçado no extrativismo, mesmo que não evidenciados.

\section{CONCLUSÃO}

A prática do extrativismo como caminho para o crescimento econômico e, consequentemente, para o desenvolvimento, tem orientado a política econômica de alguns países do Sul global desde muito tempo. Entretanto, o que se vê é a insistência em procedimentos que tem demonstrado seu impacto negativo sobre o meio ambiente, o território e o cotidiano das populações brasileiras, além da exaustão de nossos recursos naturais. Tudo isso sem retorno na forma de qualquer benefício ou justiça social. Pelo contrário, trata-se de um processo histórico de saque e apropriação colonial (ACOSTA, 2018), a partir do qual uma pequena parte da população global tem mantido, sob seu controle, os territórios e populações "tanto no que diz respeito aos bens naturais, quanto à mão de obra cada vez mais barata, e à capacidade do ambiente de absorver a contaminação e os dejetos” (LANG, 2018, p. 28). Propaga-se que não há degradação ambiental e, caso as tenha, são reversíveis - o velho e desgastado discurso da extração sustentável. Nesta narrativa, informações são omitidas e 
alguns poucos decidem o que será do conhecimentos de todos, num processo que se autofortalece, já que a parte dominante tem controle sobre essas informações.

Os discursos que sustentam o extrativismo são forjados sobre modelos positivistas e racionalistas, de roupagem tecnocrática e aparentemente neutra. Assim, existe uma ciência e um saber únicos, sobre os quais só os tecnicamente aptos - experts- poderiam opinar, tornando-se autoridades dotadas de poder. As opiniões generalistas formuladas por eles tornam-se verdades absolutas, sobre as quais as comunidades não têm conhecimento ou capacidade de opinar (GUDYNAS, 2019).

Nessa perspectiva, há diferentes violências em curso. O rompimento de uma barragem, seguida pela morte de pessoas, destruição de rios, de ecossistemas, de paisagens e de memórias é uma tragédia de grande escala, sem dúvidas. Entretanto, uma série de outros acontecimentos (ou a iminência deles) podem também atingir diferentes esferas da vida cotidiana em diferentes graus de violência. A respeito das trajetórias de determinado grupo social, Oliveira (2014, p. 37) aborda o conceito de slow violence, de Nixon:

\begin{abstract}
Suas trajetórias evidenciam o que Nixon (2006; 2011a) chamou de "violência lenta". Trata-se de uma violência silenciosa, por vezes, invisível, que rompe com a concepção de violência enquanto evento imediato e explosivo, destacando, em contraste, sua dimensão temporal extensa e seu caráter processual, a partir de uma atividade permanente e subterrânea, com potencial expansivo e cumulativo que pode ser facilmente ignorado ou elidido.
\end{abstract}

A situação atual de Raposos, assim como de diversos outros municípios do Quadrilátero Ferrífero, traz à tona a necessidade de se repensar os impactos do extrativismo. É preciso incluir nesse rol os diversos efeitos derrame que esta prática vem contabilizando nos países exportadores de matéria prima, especialmente o Brasil.

\title{
REFERÊNCIAS BIBLIOGRÁFICAS
}

ACOSTA, Alberto. Extrativismo e neoextrativismo - duas faces da mesma maldição. In: DILGER, Gerhard; LANG, Miriam; PEREIRA FILHO, Jorge (orgs.). Descolonizar o imaginário - debates sobre pós-extrativismo e alternativas ao desenvolvimento. Fundação Rosa Luxemburgo. Editora Elefante. São Paulo, p. 46-87, 2018.

ALCADIPANI, Rafael; BERTERO, Carlos Osmar. Guerra Fria e ensino do management no Brasil: o caso da FGV-

\begin{abstract}
EAESP. Revista Administração Empresas, São Paulo, v. 52, n. 3, p. 284299, Junho 2012. Disponível em: https://dx.doi.org/10.1590/S003475902012000300002 Acesso em 17 Mai. 2019.
\end{abstract}

ALVES, Débora Bendocchi. Uma região mineradora. Minas Gerais, Brasil, segunda metade do século XIX, Nuevo Mundo Mundos Nuevos [online], Colloques, 10 mars 2015. Disponível em: 
https://journals.openedition.org/nuevomun do/67741 Acesso em 18 Jan. 2019.

ANTONELLI, Mirta Alejandra. Megaminería transnacional e invención del mundo cantera. Nueva Sociedad, Nuso $\mathrm{N}^{\circ}$ 252, Julio - Agosto. Buenos Aires, 2014. Disponível em: https://nuso.org/articulo/megamineriatransnacional-e-invencion-del-mundocantera/ Acesso em 11 Mai. 2019.

BECK, Ulrich. Sociedade de Risco: rumo a uma outra modernidade. São Paulo: Editora 34, 2010.

BRASIL. Plano Nacional de Mineração 2030. Ministério de Minas e Energia. Brasília, 2011

DILGER, Gerhard; LANG, Miriam: PEREIRA FILHO, Jorge (orgs.) Descolonizar o Imaginário - Debates sobre pós-extrativismo e desenvolvimento. Fundação Rosa Luxemburgo. Editora Elefante, São Paulo, 2018.

DILGER, Gerhard; PEREIRA FILHO, Jorge. Apresentação à edição brasileira Ousar pensar "fora da caixa". In: DILGER, Gerhard; LANG, Miriam: PEREIRA FILHO, Jorge (orgs.) Descolonizar o Imaginário - Debates sobre pósextrativismo e desenvolvimento. Fundação Rosa Luxemburgo. Editora Elefante, São Paulo, p. 12-23, 2018.

DURAND, Pascal (org.). Les nouveaux mots du pouvoir. Abécédaire critique, Aden, Bruxelas, 2007.

FERRARI, J., RIERA, H. E., ZANATTA, Y. A Extensão Em Construção: Uma experiência de 'imersão' em Raposos/MG. In: XIX ENANPUR, Natal - RN, 2019. Disponível em: http://anpur.org.br/xviiienanpur/anaisadmi n/capapdf.php?reqid=1460 Acesso em 20 de jan. de 2020.
GOMES, João Oliveira. Memórias do Povo de Raposos. Ed Le, Minas Gerais. 1996.

GOMIDE, Caroline Siqueira; COELHO, Tadzio Peters; TROCATE, Charles; MILANEZ, Bruno WANDERLEY, Luiz Jardim de Moraes (orgs.). Dicionário Crítico da Mineração. 1.a ed. Marabá: iGuana, 2018.

GROSSI, Yonne de S. Mina de Morro Velho: a extração do homem. Rio, Paz e Terra. Rio de Janeiro, 1981

GUDYNAS, Eduardo. El mandato ecológico: derechos de la naturaleza y políticas ambientales en la nueva Constitución. Quito: Abya Yala, 2009.

GUDYNAS, Eduardo. Extractivismos en América del Sur y sus efectos derrame. La Revista, boletín Sociedad Suiza Americanistas, $\mathrm{N}^{\circ}$ 76, pp. 13-23, 2015

GUDYNAS, Eduardo. Extractivismos: el concepto, sus expresiones y sus múltiples violencias. Revista papeles de relaciones ecosociales y cambio global $\mathrm{N}^{\mathrm{o}} 143$ 2018, pp. 61-70. Madrid, 2018.

GUDYNAS, Eduardo. Hasta la última gota. In: RevIISE - Revista de Ciencias Soaciales y Humanas. Vol.13, número 13. Argentina, 2019. Disponível em: http://gudynas.com/wpcontent/uploads/GudynasUltimaGotaNarra tivasExtractivistas 19.pdf Acesso em 25 Abr. 2019.

IBGE - Instituto Brasileiro de Geografia e Estatística | VAB por setor de atividade em 2012. Disponível em: http://www.deepask.com/goes?page=rapos os/MG-Confira-o-PIB---Produto-InternoBruto---no-seu-municipio Acesso em 10 Out. 2018.

LANG, Miriam. Introdução- Alternativas ao desenvolvimento. In: DILGER, 
Gerhard; LANG, Miriam: PEREIRA FILHO, Jorge (orgs.) Descolonizar o Imaginário - Debates sobre pósextrativismo e alternativas ao desenvolvimento. Fundação Rosa Luxemburgo. Editora Elefante: São Paulo, p.24-46, 2018.

MADEIRA, João. Criação do Parna Gandarela perdeu chance de ser modelo, $\mathbf{O}$ Eco, 16 de outubro de 2014. Disponível em

<https://www.oeco.org.br/colunas/colunist as-convidados/28714-criacao-do-parnagandarela-perdeu-chance-de-ser-modelo/> Acesso em 12 Fev. 2019.

MILANEZ, Bruno. Mineração, ambiente e sociedade: impactos complexos e simplificação da legislação. Boletim regional, urbano e ambiental | 16 | jan.jun. IPEA. 2017

NIXON, Rob. Slow Violence, Gender and The Environmentalism of the Poor. In. Journal of Commonwealth and Postcolonial Studies. Vol. 13.2 - 14.1, 2006, p. 14- 37.

OLIVEIRA, Raquel. A Gente Tem Que Falar Aquilo Que A Gente Tem Que Provar: A geopolítica do risco e a produção do sofrimento social na luta dos moradores do Bairro Camargos em Belo Horizonte - MG. Tese de Doutorado em Sociologia, Universidade Federal de Minas Gerais, Belo Horizonte, 2014.

PLAMBEL. Informações SócioEconômicas Municipais de Raposos. Março de 1985. Disponível em: http://www.bibliotecavirtual.mg.gov.br/co nsulta/consultaDetalheDocumento.php?iCo
dDocumento $=47191$. Acesso em 16 out. 2018.

PRADO Jr., Caio. História Econômica do Brasil. Ed. Brasiliense: São Paulo, 1984.

RESENDE, Maria Leônia Chaves de; LANGFUR, Hal. Minas Gerais indígena: a resistência dos índios nos sertões e nas vilas de El-Rei. Tempo, Niterói, v. 12, n. 23, p. 5-22, 2007 . Disponível em: <http://www.scielo.br/scielo.php?script=sc i_arttext\&pid=S1413-

$77042007000200002 \& \operatorname{lng}=e n \& n r m=i s o>$. Acesso em 14 mai. 2019.

RIBEIRO, G. L. Ambientalismo e Desenvolvimento Sustentado: Nova Ideologia/Utopia do Desenvolvimento. Revista de Antropologia. São Paulo, USP, n. 34, 1991, pp. 59-101.

RIBEIRO, G. L. Poder, redes e ideologia no campo do desenvolvimento. Novos estudos - CEBRAP, São Paulo, n. 80, p. 109-125, Mar. 2008. Disponível em: <http://www.scielo.br/scielo.php?script=sc i_arttext\&pid=S0101-

$33002008000100008 \& \operatorname{lng}=e n \& n r m=i s o>$. Acesso em 10 jan. 2020.

SVAMPA, M. Consenso de los commodities, Giro Ecoterritorial y Pensamiento crítico en América Latina In: OSAL - Observatório Social de América Latina. Movimientos socioambientales en América Latina. Año XIII, $\mathrm{N}^{\mathbf{0}} 32$, noviembre de 2012. Disponível em: http://biblioteca.clacso.edu.ar/clacso/osal/2 0120927103642/OSAL32.pdf Acesso em 02 jan. de 2020.

WISNIK, José Miguel. Maquinação do Mundo: Drummond e a mineração. Ed. Companhia das Letras: São Paulo, 2018. 


\title{
WHAT IF THE DAM BURSTS? THE EXTRACTIVISM AND THE "SPREAD EFFECTS OF RISCS" IN RAPOSOS MUNICIPALITY - MG \\ Junia Ferrari | Clarice Flores Fialho | Maria Isabel Tamião Santana | Maria Moura \\ Soalheiro
}

How to cite this article: FERRARI, Junia et al. O extrativismo e os "efeitos derrame de risco" no Município de Raposos - MG. Revista de Ciências do Estado. Belo Horizonte: v. 5, n. 1, e16073. ISSN: 2525-8036.

\begin{abstract}
The discourse surrounding the idea of development has extractivism as one of the alternatives for economic growth in countries that are rich in natural resources. Minas Gerais state, in accordance with it, has sustained a relationship of historical dependence with mining, in which the accounting of profits prevails instead of many effects resulting from this practice. For sociologist Gudynas, this kind of extractivism has repercussions that go beyond the place of exploitation, affecting the environment, the territory, the economy, among others, for which he calls "spread effects". Based on it and in the study case from Raposos Municipality (MG), this paper presents a new category that includes the effects by the daily threat of bursting three local tailing dams, which we here call "risk spreads effects".
\end{abstract}

Key-worlds: development; extractivism; mining; risk; spread effect. 